\title{
SHADOWING AND INTERPRETING PERFORMANCES OF ENGLISH-MAJORED STUDENTS
}

\author{
Nguyen Thi Huyen ${ }^{1 *}$, Nguyen Thi Minh Thao ${ }^{2}$, \\ Tran Thi Dung 3 , Nguyen Tam Trang ${ }^{4}$ \\ 1. 2 and 3. Hanoi University of Industry \\ Bac Tu Liem, Hanoi, Vietnam \\ 4. Hanoi National University of Education \\ Xuan Thuy, Cau Giay, Hanoi, Vietnam \\ Received 4 December 2019 \\ Revised 13 January 2020; Accepted 15 February 2020
}

\begin{abstract}
Shadowing has widely been utilized in English language teaching classes, especially in interpretation training courses for decades and has become a topic of avid interest to various researchers such as Lambert (1992), Murphey (1995, 2001), Shiota (2012), and Hamada (2014). However, there has been no research conducted on the effect of implementing shadowing on fluency improvement in English interpretation in Vietnam. In response to this gap in the literature, this study aims to investigate (1) the possible connection between shadowing practices and the interpreting performances of the third-year English-majored students in the educational context at Hanoi University of Industry (HaUI) and (2) the students' perceptions of the application of shadowing in interpreting classes and its impacts on interpreting fluency. 54 third-year students at the Faculty of Foreign Languages (FFL), HaUI took part in a two-month experimental research, divided randomly into two groups including experimental and control groups. Data were gathered from (1) the pre- and post-tests with these two student cohorts, (2) interviews conducted with five students from the experimental group and (3) observations with this group. The research findings showed (1) a minimal influence of shadowing techniques on fluency improvement of the experimental group and (2) positive students' beliefs and attitudes towards the application of shadowing in interpreting classes and its impacts on interpreting fluency. Based on these findings, a series of recommendations on the pedagogical procedure for applying shadowing to enhance English major students' interpreting performances and further research on the application were offered. The paper, hopefully, provides useful information for teachers and researchers in the domain of interpretation, in general, and interpreting teaching activities at tertiary education, in particular.
\end{abstract}

Keywords: shadowing, interpretation, interpreting activities, fluency

\section{Introduction}

\subsection{Rationale}

Since communication within only one speech community is hardly self-sustained, and no individual in the world can know all the languages in use, there is a demand for

* Corresponding Author: Tel.: 84-974 064058

Email: nguyenthihuyen@haui.edu.vn more qualified interpreters and translators, especially in the context of increased trade globalization. To meet the increasing need in the interpreting market, there have been an ever-growing number of tertiary education institutions becoming involved in the training of interpreting and translation professionals. Faculty of Foreign Languages (FFL), Hanoi University of Industry (HaUI) is no exception. 
In order to train interpreters and translators with marketable skills, there are two multi-media classrooms equipped with Smartclass software, a computer-assisted language learning system. This system enables students to practice consecutive and simultaneous interpreting in the allowed time. Thus, both teachers and students are supported to experience more practical and effective interpreting simulations. Although students' interpreting performances have been improved gradually, particularly their memorizing and note-taking skills, some shortcomings in interpreting delivery remain due to limited fluency. It seems that they do not know how to acquire this subject to make good achievements. As a result, interpreting lecturers from the university have been continuously seeking new techniques to enhance the students' interpreting performances.

A number of pedagogical experts have been conducting research on shadowing and its effectiveness for the second language (L2) learning in general and interpreter training in particular. Briefly, according to Lambert (1992), shadowing is a language learning technique that requires the practitioner to make instant sounds to the sound stimulus signal. The method employs audio or video in a foreign language. While listening, learners attempt to repeat - to "shadow" - what they hear as fast as possible. Shadowing has been used as a helpful exercise to enhance interpreters' timing, listening and short-term memory skills simultaneously even before they start their interpreting practice (Kurz, 1992). Both Tanaka (2002) and Hamada (2012) regard shadowing as one of the techniques used for training interpreters and confirm that shadowing is effective in developing a 'good ear' for language acquisition, particularly in accent and intonation. Being aware of problems with the students' learning methods and being motivated by previous findings on shadowing, the authors conducted the investigation into a possible link between shadowing practices and FFL students' fluency in interpreting performances. This paper is hoped to be of great significance for interpretation teachers and researchers.

\subsection{Aims of the research}

This study is to evaluate the effectiveness of shadowing in interpreting performances, especially in fluency improvement, of the third-year English-majored students at FFL, HaUI and explore the students' perceptions of the application of shadowing in interpreting classes and its impacts on interpreting fluency. Then pedagogical procedures for applying shadowing are suggested.

To reach this goal, the study addressed the following questions:

1. To what extent can third-year English majored students at HaUI improve their fluency in interpreting performances by shadowing?

2. What are the students' perceptions of the application of shadowing in interpreting classes and its impacts on interpreting fluency?

\subsection{Scope}

Due to a limitation of time, the study could not delve into the effect of applying shadowing on all aspects of interpreting performances such as accuracy and language transference. The study focuses on the possible relationship between shadowing practices and fluency improvement in Vietnamese-English interpreting and the students' beliefs and attitudes towards the application of shadowing in interpreting classes and its impacts on interpreting fluency. 


\section{Literature review}

\subsection{Shadowing}

\subsubsection{Definition of shadowing}

Defined by Lambert (1992), shadowing entails a paced tracking of the heard speech in parrot-style, the word-for-word repetition of a piece of information in one language, through the headphones. Originally, shadowing is a technique used by cognitive psychologists and neuropsychologists, and utilized as a method to improve simultaneous interpretation skills. However, Hamada (2011) argues that Lambert's (1992) definition does not encompass cognitive processes, a significant concept of shadowing. He claims that shadowing should be deemed as "an active and highly cognitive activity" (p. 140) rather than the auditory repetition.

According to Tamai (2005), "shadowing is an act or task of listening in which the learner tracks the heard speech and repeats it as exactly as possible while listening attentively to the incoming information" (p.181). This definition highlights the importance of active attention to in-coming sound during the linguistic process in the human brain. Therefore, it is more suitable to apply shadowing practice in language classes.

Shadowing can be actualized in various forms, including complete, selective and interactive shadowing (Murphey, 2001). In the complete form, students repeat all the sentences stated by teachers in the audio messages. In selective shadowing, they only choose to repeat important and message-carrying parts. And finally, regarding the interactive type, learners add comments or other words while still repeating some parts of the messages. Referring to the context of Faculty of
Foreign Languages, HaUI, in interpreting lessons, teachers provide certain activities for third-year English-majored students to practice important skills for interpreting such as deciphering and memorizing skills. This is because deciphering is an indispensable step in the interpreting process while memorizing skill is one of the most important skills for interpreters. To train these skills for students, teachers ask students to listen to news in English or Vietnamese, keep in mind the idea and reproduce that message or idea in their own words. This teaching technique is quite similar to selective and interactive shadowing. Therefore, in this paper, the authors used the shadowing technique as a combination of selective and interactive forms proposed by Murphey (2001).

\subsubsection{Procedure of shadowing}

Ever since the creation of shadowing, numerous researchers and English teachers have attempted to develop this method with the aim of improving language teaching and learning. Initially, shadowing was the main technique used by interpreters in the hope of attaining fluent and accurate performance. Later on, several studies (e.g., Hamada, 2012; Kato, 2009; Oki, 2012) have investigated shadowing and demonstrated its usage in enhancing listening comprehension, speaking competence and memorizing skills. One of the typical shadowing procedures with six shadowing steps was given by Kadota and Tamai (2004) (see Table 1). 
Table 1. Shadowing Procedure of Katoda and Tamai (2004)

\begin{tabular}{|l|l|l|l|}
\hline No. & Steps & Tasks & Focuses \\
\hline 1 & Listening & $\begin{array}{l}\text { Listening to the audio without } \\
\text { script }\end{array}$ & Content and speech style \\
\hline 2 & Mumbling & $\begin{array}{l}\text { Shadowing without the script } \\
\text { (content understanding) }\end{array}$ & Heard sound rather than pronunciation \\
\hline 4 & Prosody shadowing & Shadowing with the script & $\begin{array}{l}\text { Prosodic features (stress, rhythm, } \\
\text { intonation, speed, and pause) }\end{array}$ \\
\hline 5 & $\begin{array}{l}\text { Synchronized reading } \\
\text { (difficult points) }\end{array}$ & Shadowing with the script & Parts difficult to listeners \\
\hline 6 & Content shadowing & Shadowing without the script & Content \\
\hline
\end{tabular}

\subsection{Interpreting definitions and modes}

Interpreting takes a key role in bridging the gap between two different languages and cultures, helping people of different languages to understand what is being said. There are various definitions of interpreting. Roderick Jones, a European Union senior conference interpreter, states that interpreting is "immediate oral translation", instead of offering a "standard" definition (2002, p. 3). Interpreting, just like translation, is fundamentally"theartofre-expressing"(Hanh, 2006, p. 8). The interpreter listens to a speaker in one language, grasps the content of what is being said and then verbally re-expresses his or her understanding of the meaning in the target language. More specifically, according to Mahmoodzadeh (1992, p. 231), interpreting "consists of presenting in the target language, the exact meaning of what is uttered in the source language either simultaneously or consecutively, preserving the tone of the speaker". In general, in this study, interpreting is rendering information and ideas from one language into another language by means of speaking.

Based on working mode, interpreting is classified into two main models: simultaneous and consecutive interpreting (Bui \& Dang, 1999). In simultaneous interpreting, an interpreter has to interpret nearly at the same time as the speaker, so the task of interpreting is very demanding and challenging. Due to the high level of difficulty, simultaneous interpreting is briefly introduced for students' information rather than being part of the training course for the third-year students at FFL, HaUI. Unlike simultaneous interpreting, consecutive interpretation is defined as "the process of interpreting after the speaker or signer has completed one or more ideas in the source language and pauses while the interpreter transmits that information" (Russell, 2005, p.136). However, this study proposes that whether interpreting consecutively or simultaneously, the interpreter has to attentively listen to the speaker, exactly understand, logically analyze the meaning of the message, then accurately and naturally convey the message in the target language. Hence, some helpful skills including note-taking skills, short-term memory, reproduction, and listening comprehension are required for a good interpreter.

\subsection{Criteria of interpreting assessment}

This study contends that interpreting requires language users to master a wide range of aspects such as background knowledge, cultures and language competence. However, it is difficult to decide whether an interpreting version is acceptable or not. Therefore, the assessment of interpreting versions has been a 
controversial topic which draws considerable concerns to linguistic researchers. According to the study by Zwischenberger (2010), there are three main criteria to evaluate interpreting assignments (see Table 2).

Table 2. Criteria for Interpreting Assessment

\begin{tabular}{|l|l|l|}
\hline Content-related criteria & Form-related criteria & Delivery-related criteria \\
\hline Sense consistency with the original & Correct terminology & Fluency of delivery \\
\hline Logical cohesion & Correct grammar & Lively intonation \\
\hline Completeness & Appropriate style & Pleasant voice \\
\hline & & Synchronicity \\
\hline
\end{tabular}

It is remarkable that fluency is regarded as the most important delivery-related criterion by $99.3 \%$ of Zwischenberger's (2010) online survey participants. However, Richards (1990) states that fluency is a fuzzy concept with a variety of definitions. Lennon (1990) argues that there are two senses of fluency: a broad and a narrow sense. In a broad sense, fluency refers to general oral proficiency. This view includes smoothness as only one component of overall fluency. In a narrower sense, fluency can be considered as a component of oral proficiency which consists of other variables such as correctness, appropriateness, pronunciation, and lexical range. Therefore, it is possible to conclude that someone can speak a given language fluently, but his or her grammar is not accurate. In a later study, Lennon (2000) summarized earlier definitions and suggests that "fluency might be the rapid, smooth, accurate, lucid, and efficient translation of thought or communicative intention into language under the temporal constraints of on-line processing" (p. 26). Fluency has been so far measured by calculating the number of words per minute (Skehan \& Foster, 1999). The authors in this research also use these criteria to assess the students' interpreting performances during interpreting lessons. Students' interpreting versions are recorded and saved on Smart class system, and their fluency was evaluated based on the number of words per minute/second.
2.4. A possible connection between shadowing practices and the interpreting performance

As mentioned earlier, shadowing was initially the main technique used by interpreters to promote fluent and accurate performance in interpreting practices. Up to now, many researchers have placed much emphasis on the role of shadowing in improving the quality of interpreting assignments. Converging with other researchers (e.g., Hamada, 2012; Kanatani et al., 2010), Tanaka (2002) affirms that shadowing is one of the effective techniques for interpreter training. Kurz (1992) also states that shadowing is an exercise to enhance simultaneous interpreters' timing, listening and short-term memory skills. Kadota (2007) argues that shadowing process engages diversified areas of the listener's brain, encompassing those of language and memory. Among three kinds of memory, namely sensory memory, short-term or working memory, and long-term memory, shadowing contributes to increasing the quantity and the storing period of the phonological information in the working memory (Kadota, 2007).

\section{Methodology}

\subsection{Research site and participant selection}

As mentioned earlier, the research was conducted at Faculty of Foreign Languages 
(FFL), Hanoi University of Industry (HaUI), where English major students are trained to become future professional interpreters or translators. At the FFL, HaUI, the third-year English-majored students started taking the Interpreting Course in the second semester of the academic year. Since the students had not learnt this subject before, their interpreting performances, especially their fluency in Vietnamese-English interpreting, were limited. Indeed, this is a common situation that the authors have observed for many years of teaching interpreting. Thus, the third-year students at FFL, HaUI were selected to be the participants of this study. However, there are two labs with 54 computers assisted with Smart class system in total, so 54 third-year English majors of the FFL, at HaUI, including 6 males and 48 females, were randomly chosen from classes and equally separated into two groups, the experimental and the control. The students studied interpreting for 15 weeks, four class hours per week.

\subsection{Data collection tools and procedures}

In order to answer the two research questions, the authors took a mixed approach of experimental research. The authors first collect quantitative data through the preand post-tests to address whether shadowing practices had an impact on the interpreting fluency of the third-year students atFFL, HaUI. After the intervention concluded, the authors collected qualitative data from interview and observation to have a potential understanding of the students' beliefs and attitudes towards the application of shadowing practices in interpreting courses and its impacts on their interpreting fluency.

First, the experimental research was conducted in 8 weeks during the semester including one week for a pre-test (see Appendix A), six weeks for shadowing practices applied for the experimental group and one week for a post-test (refer to Appendix B). Both the control group and the experimental group took the same pre- and post-test on the 3rd and 10th week of the semester, respectively. The pre-test and post-test were carefully selected from the test bank of interpreting and edited in terms of topic relevance, lexical and grammatical difficulties. There were three topics covered in the experiment, namely Tourism, Environment, and Economy. News pieces of 55-70 words in length with a recorded speed of 120-130 words per minute (wpm) were chosen to suit the students' expected B2 level of English proficiency. The lexical and grammatical difficulties in the news were at B1, based on Aptis General Technical Manual, British Council, 2015 with Flesch-Kincaid grade level at 6-9 or Flesch Reading ease at $80-60$ and K1-K3 of $90-95 \%$. The teachers of the two groups were trained to use a rubric (see Appendix C) to assess the students in terms of given criteria for interpreting assessment. The overall results of interpreting performances and of fluency were taken into consideration in this study. During the whole semester, both groups followed the usual procedure of an interpreting lesson in which they got involved in the activities to practice important interpreting skills such as memorizing and deciphering skills. Only the experimental group engaged in shadowing practices. The teacher of the experimental group trained the students to practice shadowing in interpreting at week 6 of the semester. The experimental group applied shadowing practices from week 4 to week 9 .

Second, observation during the sixweek shadowing practices at the lab where the experimental group studied was also conducted focusing on certain prepared elements as specified in the section discussing interpreting assessment criteria. In particular, the observation focused on the following aspects: 
- Students' participation and attitudes towards interpreting activities using shadowing practices;

- Ability to memorize the idea and reproduce that message meaning in the source language in front of the class within five-ten seconds;

- Ability to promptly deliver the message meaning into the target language.

Third, semi-structured one-on-one interviews composed of six questions designed by the authors (see Appendix D) were carried out. The authors chose randomly 5 out of 27 students from the experimental group to interview to elicit more detailed feedback on the effectiveness of applying shadowing technique in the interpreting lessons. Observations and interviews were undertaken with the experimental group only.

\subsection{Data analysis and interpretations}

The results of the tests were analyzed with the help of Excel Data Analysis and displayed in the form of statistics. The data collected from the interviews and observations were analyzed in a theme-based approach.

\section{Findings and discussion}

The major results of the study are summarized as follows:

Question 1: To what extent can thirdyear English major students at HaUI improve their fluency in interpreting performances by shadowing?

The descriptive statistics of the fluency results of two tests for both groups (see Table 3 ) show that the students' interpreting fluency improved, albeit insignificantly, after the experiment. The data reveal that the fluency of the experimental group experienced a minimal improvement from 6.42 to 7.0. Also, it was only marginally better than that of the control group, 7.0 as opposed to 6.74 .

Table 3. Descriptive Statistics of Pre-test and Post-test of the Experimental Group and Control Group

\begin{tabular}{|l|l|l|l|l|l|}
\hline Groups & Tests & Means & SD & Min & Max \\
\hline \multirow{2}{*}{ Experimental group } & Pre-test & 6.42 & 0.84 & 5.0 & 8.0 \\
\cline { 2 - 6 } & Post-test & 7.0 & 0.73 & 5.5 & 9.0 \\
\hline \multirow{2}{*}{ Control group } & Pre-test & 6.46 & 0.89 & 5.0 & 8.0 \\
\cline { 2 - 6 } & Post-test & 6.74 & 0.86 & 5.5 & 8.5 \\
\hline
\end{tabular}
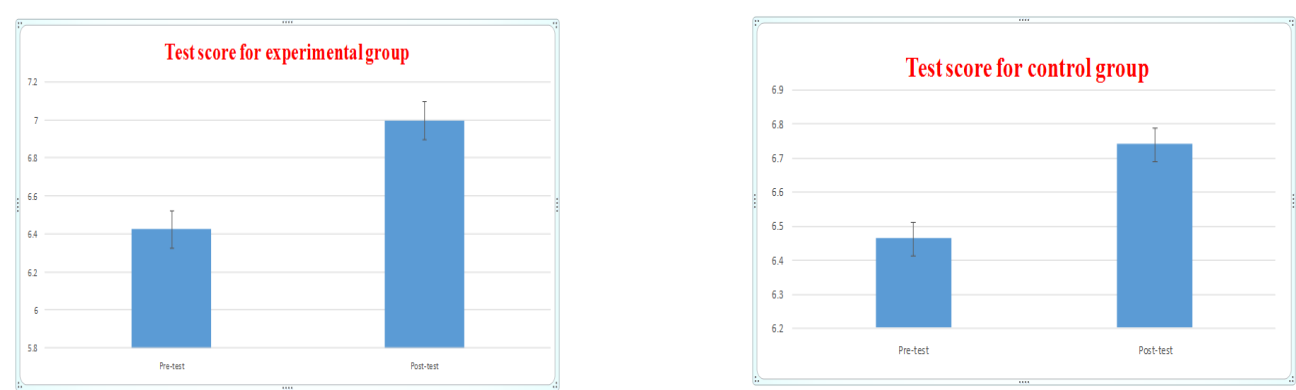

Graph 1. Test Score for Experimental Group and Control Group

It can be seen from Graph 1 that although both groups did show the sign of improvement in both tests, the experimental group increased their scores faster than those of the control group after undergoing shadowing within 6 weeks. Therefore, the effect of shadowing was obviously true for the students in this study. It is also noticeable that the mean and maximum 
scores of the control group were even higher than those of its counterpart, confirming the reliability resulting from random selection of participants.

However, the minority of the students in the experimental group did not enhance their interpreting performance, especially in their fluency in terms of Vietnamese-English interpreting when they finished the six-week shadowing training (see Table 4 and Table 5 for the average speed in wpm). The data show that the pre- and post-test scores of these students remained the same.

Table 4. Fluency in English-Vietnamese Interpreting

\begin{tabular}{|l|l|l|}
\hline & Pre-test & Post-test \\
\hline Experimental group & 119 & 131 \\
\hline Control group & 120 & 126 \\
\hline
\end{tabular}

Table 5. Fluency in Vietnamese-English Interpreting

\begin{tabular}{|l|l|l|}
\hline & Pre-test & Post-test \\
\hline Experimental group & 103 & 124 \\
\hline Control group & 106 & 115 \\
\hline
\end{tabular}

Either the marginal development or the insignificant difference in the students' interpreting fluency recorded after the intervention, despite the students strictly following the procedure suggested by the teachers, might happen because the students did not practise shadowing long enough at class. Another possible reason may be because the students were not required to selfpractice this technique more at home. Also, the teachers did not use on-going assessments such as a mid-term test or several mock tests or mini-tests as well as self- and peerassessments from students to work out the strengths and weaknesses of the students in their interpreting performances. As a result, both the teachers and the peers could not suggest what the students should do to further enhance their interpreting performances.
Question 2: What are the students' perceptions of the application of shadowing in interpreting classes and its impacts on interpreting fluency?

Through observations during shadowing practices in the lab room at FFL, HaUI, the authors found that the students were more engaged and interested in interpreting lessons when following shadowing strategy. 100 percent of the students paid special attention to listen to the audios to shadow as much as possible. More interestingly, they could shadow most of the content of Vietnamese news in the first time of listening. Observing the students shadowing English news, the researchers also saw that the students demonstrated their excitement when comparing their shadowing versions without scripts to those with given scripts. The researchers overheard some of the students say "Oh, no. It's totally different from what I heard" or "Wow. I got $80 \%$ of the communicated message" or "Shadowing looks like a good way to memorize and decipher the message before interpreting".

Besides, the results from the interviews with the students showed that all interviewees remembered and perceived to follow the procedure suggested by the authors. Also, four out of five said that the procedure was useful for them. 95 per cent of the students in the interviews said that their fluency, especially in terms of English-Vietnamese interpreting had been greatly improved. More surprisingly, three out of five students believed that shadowing practices can help enhance their memory skill, concentration, and the ability to listening comprehension and reproduction in the source language. These students also expected that their teachers would apply shadowing practices in interpreting lessons next semester. This suggests that the students had positive perceptions on the application of shadowing in interpreting and its impacts on 
improving their interpreting performances. This might create more motivations for the students which is significant in their further practice with shadowing at class and at home under the teachers supervision and guidance.

\section{Conclusion and implications}

As an improvement of interpreting skills is nearly impossible if the process of learning is implemented without any techniques, thirdyear English majors are supposed to fiercely stick to their own suitable methods. Therefore, shadowing was presented to them as the subject of the study in hope of suggesting a new learning tactic to ultimately strengthen their Vietnamese-English interpreting performances in general and their fluency in particular.

In order to reach this goal, two tests were conducted on with 54 third-year students studying at the Faculty of Foreign Languages of Hanoi University of Industry. Participants were divided into two groups, the experimental group and control group, with the first group being thoroughly trained with shadowing and practicing this technique at class within six weeks under the strict supervision of the researchers. The results of the experiment displayed the level of impact of shadowing on Vietnamese-English interpreting performances, especially in their fluency.

The test results indicate that the interpreting performance, especially fluency, of the experimental group slightly outpaced to that of the control group although both of them ended up with a minimal increase in their scores. The data collected from interviews and observations demonstrate that the students had positive beliefs and attitudes towards the application of shadowing practices in interpreting and its influence on their interpreting fluency.

Though the authors have made efforts towards conducting this study, due to the limitations of knowledge, research skills and time as well, errors and shortcomings are unavoidable. First and foremost, the experiment was conducted within a short period of six weeks. In addition, observations and interviews were implemented with only the experimental group, instead of both groups. The observations were conducted without a protocol which might be useful for the researchers to record the students' perceptions. The fact that the interviewees exclude the teachers and that the student interviewees were selected randomly may not yield the richest data from different perspectives. Besides, the other aspects of interpreting were not measured and reported, including accuracy and language transference. Also, the minimal development or indifferences in interpreting performances, especially fluency, of some students in the experimental group raise a concern on why shadowing did not exert much influence on them. Finally, a detailed syllabus with specific activities for shadowing practices and on-going assessments by teachers and students was not utilized. These limitations should be addressed in further studies.

Due to the distinct features of the interpreting training session, the researchers suggest a procedure of shadowing practices in interpreting lessons which is adapted from the Kadota and Tamai's procedure (see Appendix E). The procedure of shadowing in interpreting lessons consists of five steps namely listening, mumbling, synchronized reading (content understanding), content interpreting and completing interpreting. This is because interpreters must initially have excellent hearing ability and receive the message without interference. Lack of understanding can lead to a breakdown of communication (Bui \& Dang, 1999). Sometimes, speakers express their ideas redundantly or vaguely, and even use cultural terms in their speech; therefore, students can shadow with edited information 
as long as the main ideas of the message remain. Furthermore, during interpreting process, interpreters have to transfer the message into the target language exactly, completely and naturally as much as possible, and refer to culture of source language and target language as well as the context when necessary, so the fluency, accuracy, language transference of the target language are focused in the fifth step of interpreting. In order to achieve more significant impacts on students' interpreting performances, teachers can instruct students how to practice shadowing and apply this technique repeatedly for a long time both at class and at home throughout a 15-week course. Teachers may also utilize on-going assessments with a combination of assessment from teachers as well as self- and peer-assessments from students to figure out students' strengths and weaknesses. After that, both teachers and peers might give suggestions on how to improve students' interpreting performances.

\section{References}

Bui, B. T., \& Dang, D. X. (1999). Translation and interpreting theory. Hanoi: Hanoi University of Foreign Studies.

Hamada, Y. (2011). Improvement of listening comprehension skills through shadowing with difficult materials. The Journal of Asia TEFL, 8, 139-162.

Hamada, Y. (2012). An effective way to improve listening skills through shadowing. The Language Teacher, 26, 3-10.

Hamada, Y. (2014). The effectiveness of pre- and postshadowing in improving listening comprehension skills. The Language Teacher, 38(1), 3-10.

Jones, R. (2002). Conference interpreting explained. St. Jerome Publishing.

Katoda, S., \& Tamai, K. (2004). English shadowing. Tokyo: Cosmopier.

Kadota, S. (2007). Shadowing to ondoku no kagaku [Science of shadowing and oral reading]. Tokyo: CosmoPier.
Kato, S. (2009). Listening activities for the acquisition of Aviation English proficiency test. Bulletin of Chiba University Language and Culture, 3, 47 - 59.

Kanatani, K., et al. (2010). Taishukan's TEFL handbookfor junior high school teachers. Tokyo: Taishukan Shoten.

Kurz, I. (1992). 'Shadowing' exercises in interpreter training. In C. Dollerup \& A. Loddegaard (Eds.), Teaching translation and interpreting: Training, talent, and experience (pp. 245-250). Amsterdam: John Benjamins Publishing Company.

Lambert, S. (1991). Aptitude testing for simultaneous interpretation at the University of Ottawa. Mcta: Translators' Journal, 36, 586-594.

Lambert, S. (1992). Shadowing. Méta, 37(2), 263-273.

Lennon, P. (1990). Investigating fluency in EFL: A quantitative approach. Language Learning, 40 (3), 387-417.

Lennon, P. (2000). The lexical element on spoken second language fluency. In H. Riggenback (Ed.), Perspectives on fluency (pp. 26). Ann Arbor: University of Michigan Press.

Mahmoodzadeh, K. (1992). Consecutive interpreting: Its principles and techniques. In C. Dollerup \& A. Loddegaard (Eds.), Teaching translation and interpreting: Training, talent, and experience (pp. 231-236). Amsterdam: John Benjamins Publishing.

Murphey, T. (1995). Conversational shadowing for rapport and interactional language acquisition. In Proceedings of The 6th Conference on Second Language Research in Japan, 42-65.

Murphey, T. (2001). Exploring conversational shadowing. Language Teaching Research, 5(2), 128-155.

Oki, T. (2012). Word repetition in EFL shadowing: The roles of phrasal knowledge, context, and proficiency. Annual Review of English Language Education in Japan, 23, 45-60.

Pham, H. H. (2006). Note taking in consecutive interpreting. Hanoi: Hanoi University of Foreign Studies.

Richards, J. (1990). The language teaching matrix. Cambridge, UK: Cambridge University Press.

Russell, D. (2005). Consecutive and simultaneous interpreting. In: T. Janzen (Ed.) Topics in signed language interpreting (pp. 135-164). Amsterdam: John Benjamins Publishing.

Shiota, K. (2012). The effectiveness of shadowing on students' psychology in language learning. Journal of Accents Asia, 5(1), 71-83. 
Skehan, P., \& Foster, P. (1999). The influence of task structure and processing conditions on narrative retellings. Language Learning, 49(1), 93-120.

Tamai. K. (2005). Listening shidouhotoshite no shadowing no koukani kansuru kenkyu [Research on the effectiveness of shadowing as a listening teaching method). Tokyo: Kazama Shobo.
Tanaka, M. (2002). Modern interpreting: Where English education and interpreter training intersect. TsuyakuHonyaku Journal, 1. Retrieved from http://wwwsoc.nii. ac.jp/jais/html/tu_hon_journal/html/09_tanaka.html

Zwischenberger, C. (2010). Quality criteria in simultaneous interpreting: An international vs. a national view. The Interpreters' Newsletter, 15, 127-142.

\title{
PHƯƠNG PHÁP SHADOWING VÀ KHẢ NĂNG PHIÊN DICCH THỰC TẾ CỦA SINH VIÊN CHUYÊN NGÀNH NGÔN NGŨ ANH
}

\author{
Nguyễn Thị Huyền ${ }^{1}$, Trần Thị Dung ${ }^{2}$, Nguyễn Thị Minh Thảo ${ }^{3}$, \\ Nguyễn Tâm Trang ${ }^{4}$ \\ 1,2 và 3. Trường Đại học Công nghiệp Hà Nội \\ Bắc Tù̀ Liêm, Hà Nội, Việt Nam \\ 4. Truờng Đại học Su phạm Hà Nội \\ Xuân Thủy, Cầu Giấy, Hà Nội, Việt Nam
}

Tóm tắt: Phương pháp Shadowing từ lâu đã được ứng dụng rộng rãi trong các lớp học tiếng Anh, đặc biệt trong các khóa đào tạo phiên dịch và là mảng đề tài nhiều học giả quan tâm nghiên cứu như Lambert (1992), Murphey (1995, 2001), Shiota (2012), Hamada (2014). Tuy nhiên, cho tới nay, chưa có nghiên cứu nào ở Việt Nam tìm hiểu về tác dụng của phương pháp Shadowing trong việc nâng cao khả năng phiên dịch lưu loát tiếng Anh. Để khắc phục khoảng trống nghiên cứu đó, nghiên cứu này được thực hiện nhằm tìm ra (1) mối liên hệ giữa việc thực hành phương pháp Shadowing với khả năng phiên dịch trên thực tế của sinh viên năm thứ ba chuyên ngành ngôn ngữ Anh trường Đại học Công nghiệp Hà Nội (ĐHCNHN) và (2) quan điểm của sinh viên về việc ứng dụng kỹ thuật Shadowing trong các lớp học dịch và ảnh hưởng của việc ứng dụng này đối với khả năng dịch lưu loát. Có 54 sinh viên tham gia nghiên cứu thực nghiệm trong hai tháng, được chia ngẫu nhiên vào nhóm thực nghiệm và nhóm đối chứng. Dữ liệu nghiên cứu được thu thập từ bài kiểm tra trước và sau khi tiến hành thực nghiệm với hai nhóm sinh viên này, (2) phỏng vấn năm sinh viên ở nhóm thực nghiệm và (3) dự giờ quan sát với nhóm này. Kết quả nghiên cứu cho thấy (1) luyện tập Shadowing đóng vai trò tương đối trong việc cải thiện khả năng dịch lưu loát của sinh viên nhóm thực nghiệm và (2) sinh viên có thái độ và quan điểm tích cực đối với việc ứng dụng kỹ thuật Shadowing trong các lớp học dịch và ảnh hưởng của việc ứng dụng này đối với khả năng dịch lưu loát. Dựa trên những kết quả nghiên cứu này, nhóm tác giả đề xuất một quy trình áp dụng phương pháp shadowing nhằm nâng cao khả năng dịch lưu loát cho sinh viên chuyên tiếng Anh tại trường ĐHCNHN và gợi ý những hướng nghiên cứu tiếp theo cho việc áp dụng này. Bài viết hi vọng sẽ là nguồn thông tin hữu ích cho giảng viên và các nhà nghiên cứu về dịch thuật nói chung cũng như gợi ý các hoạt động giảng dạy phiên dịch tại các trường đại học nói riêng.

Từ khóa: Shadowing, phiên dịch, các hoạt động phiên dịch, dịch lưu loát 


\section{Vietnamese news}

\section{Appendix A: Pre-test}

Bộ Tài nguyên và Môi trường cho biết, năm nay Ngày môi trường thế giới (5/6) đã được tổ chức tại TP HCM với chủ đề "Hãy hành động để ngăn nước biển dâng" nhằm nhấn mạnh tầm quan trọng của bảo vệ môi trường, ứng phó với biến đổi khí hậu đối với các khu vực dễ bị ảnh hưởng như hải đảo và các khu vực ven biển.

\section{English news}

Tenerife, the largest of the Canary Islands, is situated in the Atlantic Ocean. The island enjoys spring weather all year round. It has the average temperatures of 20 degrees in winter and 25 in the summer. Tenerife is the ideal place to enjoy the seaside. Tourists also practice all sorts of outdoor activities, both in the sea and on land.

\section{Vietnamese news}

\section{Appendix B: Post-Test}

Dự đoán là hòn đảo sẽ "gây sốt” năm 2017, đảo Điệp Sơn là địa danh nhất định mang đến cho bạn nhiều trải nghiệm bất ngờ, lý thú.Thời điểm đẹp nhất để du lịch đảo Điệp Sơn là từ tháng 12 đển tháng 6 vì biển khá êm và trong xanh, nên những bạn bị say sóng sẽ giảm được nhiều khó chịu khi di chuyển bằng tàu.

\section{English news}

The first Earth Day celebrations took place in more than twelve thousand schools and hundreds of communities across the United States. It now is popular in 192 countries. According to the first Earth Day 1970 organizer Denis Hayes, "it is the largest holiday in the world. It is celebrated by more than a billion people every year".

\section{Appendix C: Interpreting Assessment Criteria}

Date:

Student's name:

Student's ID:

Recorder number:

File number:

Teacher's name:

\begin{tabular}{|l|l|l|l|l|l|l|l|l|l|l|}
\hline \multicolumn{1}{|c|}{ Assessing criteria } & \multicolumn{7}{c|}{ Rating scale } \\
\hline Content-related criteria & 1 & 2 & 3 & 4 & 5 & 6 & 7 & 8 & 9 & 10 \\
\hline Sense consistency with the original & & & & & & & & & & \\
\hline Logical cohesion & & & & & & & & & & \\
\hline Completeness & & & & & & & & & & \\
\hline Form-related criteria & 1 & 2 & 3 & 4 & 5 & 6 & 7 & 8 & 9 & 10 \\
\hline Correct terminology/ Word choice & & & & & & & & & & \\
\hline Correct grammar & & & & & & & & & & \\
\hline Appropriate style & & & & & & & & & & \\
\hline Delivery-related criteria & 1 & 2 & 3 & 4 & 5 & 6 & 7 & 8 & 9 & 10 \\
\hline Fluency of delivery & & & & & & & & & & \\
\hline Lively intonation & & & & & & & & & \\
\hline Pleasant voice & & & & & & & & \\
\hline Synchronicity & & & & & & & & & \\
\hline & & & & & & & & & & \\
\hline
\end{tabular}

Notes: 


\section{Appendix D: Interview}

1. Before taking part in this research, have you ever practiced shadowing by yourself to improve your English in general and interpreting in particular?

2. How often do you practice shadowing in this research?

3. Besides the given lessons in the textbook of interpreting 1, do you practice shadowing on other sources? If yes, clarify your answer.

4. Do you think the procedure for shadowing practice given by the researchers is useful for you? If no, what suggestions would you like to give?

5. Do you think your interpreting performance is getting better by shadowing practices? If yes, which aspect(s) do you improve the most? (fluency, accuracy, language transference, memorizing skill, concentration, reproduction, note-taking, listening comprehension...)

6. Would you like your teachers to apply shadowing practices in interpreting lessons next semester? Give reasons for your answer?

Appendix E: A Suggested Procedure of Shadowing in Interpreting Lessons

\begin{tabular}{|c|c|c|c|c|}
\hline No. & Steps & Tasks & Focuses & Notes \\
\hline 1 & Listening & $\begin{array}{l}\text { Listening to the audio } \\
\text { without script }\end{array}$ & $\begin{array}{l}\text { Content and speech } \\
\text { style }\end{array}$ & \\
\hline 2 & Mumbling & $\begin{array}{l}\text { Shadowing without the } \\
\text { script }\end{array}$ & $\begin{array}{l}\text { Heard sound rather } \\
\text { than pronunciation }\end{array}$ & \\
\hline 3 & $\begin{array}{l}\text { Synchronized read- } \\
\text { ing } \\
\text { (content under- } \\
\text { standing) }\end{array}$ & $\begin{array}{l}\text { Shadowing with the giv- } \\
\text { en script }\end{array}$ & Message meaning & $\begin{array}{l}\text { Students can shad- } \\
\text { ow with their edited } \\
\text { information, as long } \\
\text { as the main ideas of } \\
\text { the message remain } \\
\text { / are retained. }\end{array}$ \\
\hline 4 & Content interpreting & $\begin{array}{l}\text { Interpreting briefly some } \\
\text { segments of the messag- } \\
\text { es with a script }\end{array}$ & $\begin{array}{l}\text { The target lan- } \\
\text { guage of listeners } \\
\text { (stress, rhythm, } \\
\text { intonation, speed, } \\
\text { pause) }\end{array}$ & \\
\hline 5 & $\begin{array}{l}\text { Completing inter- } \\
\text { preting }\end{array}$ & $\begin{array}{l}\text { Interpreting the whole } \\
\text { message }\end{array}$ & $\begin{array}{l}\text { The fluency, ac- } \\
\text { curacy, language } \\
\text { transference of the } \\
\text { target language }\end{array}$ & \\
\hline
\end{tabular}

